\title{
A CASE STUDY
}

\section{Crop diversification to enhance nutrient use efficiency in Indian scenario}

\author{
AMRENDRA KUMAR* ${ }^{*}$ TANUMAY MANDAL ${ }^{3}$, QURESHI AMEEN ${ }^{1}$ AND SUNIL KUMAR ${ }^{2}$ \\ Department of Agronomy, Sugarcane Research Institute, Rajendra Agricultural University, \\ Pusa, SAMASTIPUR (BIHAR) INDIA \\ (Email : amrendra7009@gmail.com)
}

\begin{abstract}
Indian agriculture is now facing second generation problems like raising or lowering of water table, nutrient imbalance, soil degradation, salinity, resurgence of pests and diseases, environmental pollution and decline in farm profit. About 2.5 million tone of additional food grains are required annually in the next 10 years to meet the demand of the growing population. This is a huge challenge as it has to come from shrinking both in quality and quantity. Crop diversification shows lot of promise in alleviating these problems through fulfilling the basic needs and regulating farm income, withstanding weather aberrations, controlling price fluctuation, ensuring balanced food supply, conserving natural resources, reducing the chemical fertilizer and pesticide loads, environmental safety and creating employment opportunity.
\end{abstract}

Key Words : Crop diversification, Management, Nutrient use efficiency

View Point Article : Kumar, Amrendra, Mandal, Tanumay, Ameen, Qureshi and Kumar, Sunil (2016). Crop diversification to enhance nutrient use efficiency in Indian scenario. Internat. J. agric. Sci., 12 (1) : 139-142.

Article History : Received : 11.12.2015; Accepted : 27.12.2015

\footnotetext{
* Author for correspondence

${ }^{1}$ Rice Research Sub Station (R.A.U.) Jhanjharpur, MADHUBANI (BIHAR) INDIA

${ }^{2}$ Indira Gandhi Krishi Vishwavidyalaya, RAIPUR (C.G.) INDIA

${ }^{3}$ Department of Agronomy, Govind Ballabh Pant University of Agriculture and Technology, PANTNAGAR (UTTARAKHAND) INDIA
} 